\title{
New Protocol-Guided Exploitation of a Lysosomal \\ Sulfatase Inhibitor to Suppress Cell Growth in Glioblastoma Multiforme
}

Meng-meng Zhang, ${ }^{1,2}$ Yan Jia,Peng Li, ${ }^{3}$ Yan Qiao4 and Ke-Li Han*1

${ }^{1}$ State Key Laboratory of Molecular Reaction Dynamics, Dalian Institute of Chemical Physics, Chinese Academy

of Sciences, Dalian 116023, P. R. China.

${ }^{2}$ University of the Chinese Academy of Sciences, Beijing 100049, P. R. China.

3 Institute of Molecular Sciences and Engineering, Shandong University, Qingdao 266237, P. R. China.

${ }^{4}$ College of Chemistry, Institute of Green Catalysis, Zhengzhou University, 100 Science Avenue, Zhengzhou, Henan Province, 4500o1, P. R. China 


\section{List of content}

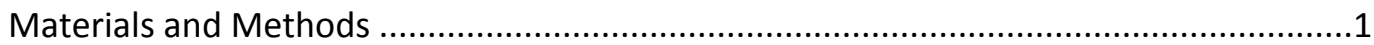

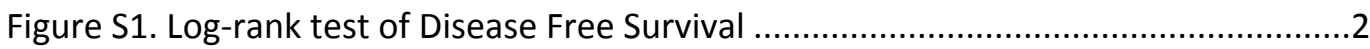

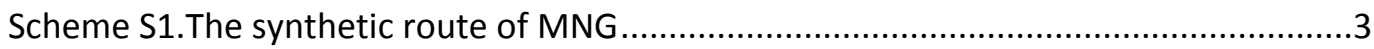

Figure S2.Absorption and fluorescence spectra of MNG and MN .................................

Figure S3. Verify metabolic reaction by MNG.............................................................

Figure S4. The response of other biomolecules...........................................................6

Figure S5.The $\mathrm{pH}$ effect of MNG and MN..............................................................

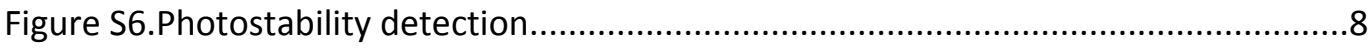

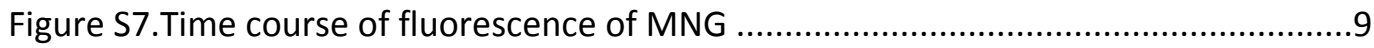

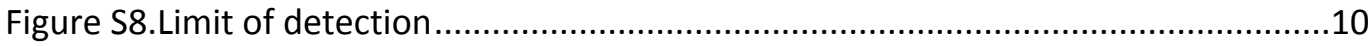

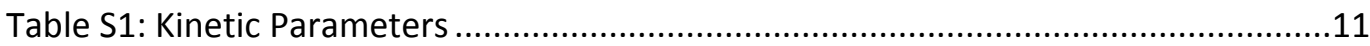

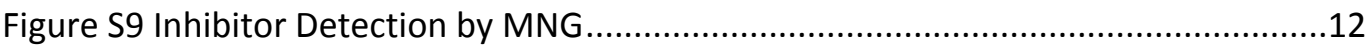

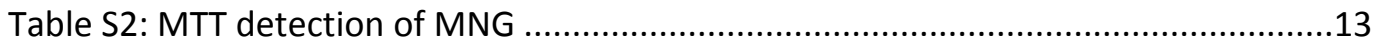

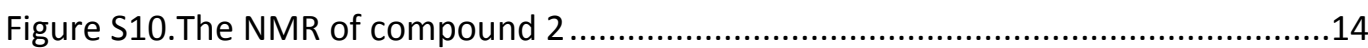

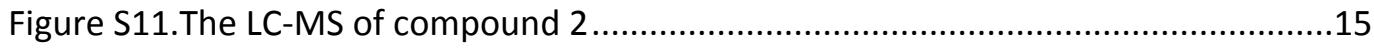

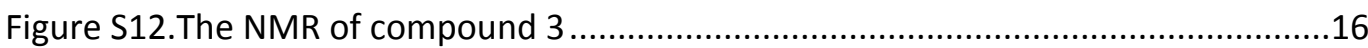

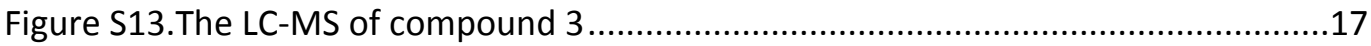

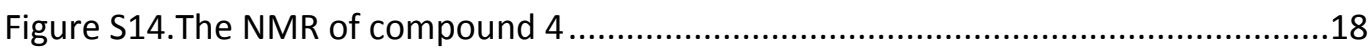

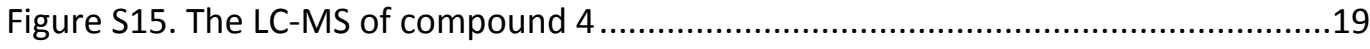

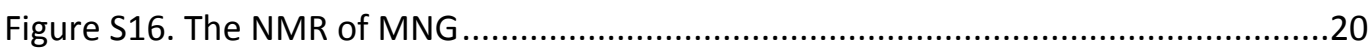

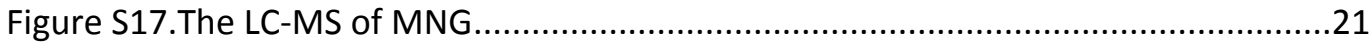

Table S3. The detailed docking information of complex by molecular docking ..............22

Figure S18. Root-mean-square Deviation (RMSD) of 20 ns MD Simulations...................23

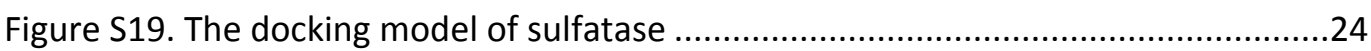

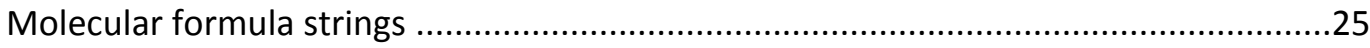

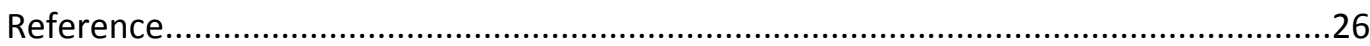




\section{Materials and Methods}

\section{Reagents and instruments}

All solvents are purchased from Sigma-Aldrich and all reagents for the cell culture were purchased from Gibco Life Technologies (Grand Island, NY, USA), unless otherwise stated. The T98G cell line was purchased from the American Type Culture Collection (ATCC, Manassas, VA, USA). Sulfatase of helix pomatia was purchased by Bioruler. MTT Cell Proliferation and Cytotoxicity Assay Kit and Lyso-Tracker Red were purchased by Beyotime. The inhibition library was purchased from MedChemExpress. Chemical characterization was performed by Bruker 400M NMR spectrometer (AVANCE III $400 \mathrm{MHz}$ ) and Q-TOF 6540 chromatography. Confocal fluorescence images were observed with Olympus FV1000 confocal laser-scanning microscope with an objective lens. 96-well plate fluorescence is detected by Thermo Scientific Microplate Reader.

\section{Statistical analysis}

Plotting and statistical analysis were performed in GraphPad Prism software. All the experiments were repeated at least three times unless otherwise noted. All quantitative data were presented as the mean SEM (standard error of the mean) or the mean SD (standard deviation) as indicated of at least three independent experiments. And comparisons between two groups were analyzed using two-tailed t-tests. $p<0.05$ was defined as significant. 


\section{Figure S1. Log-rank test of Disease Free Survival}

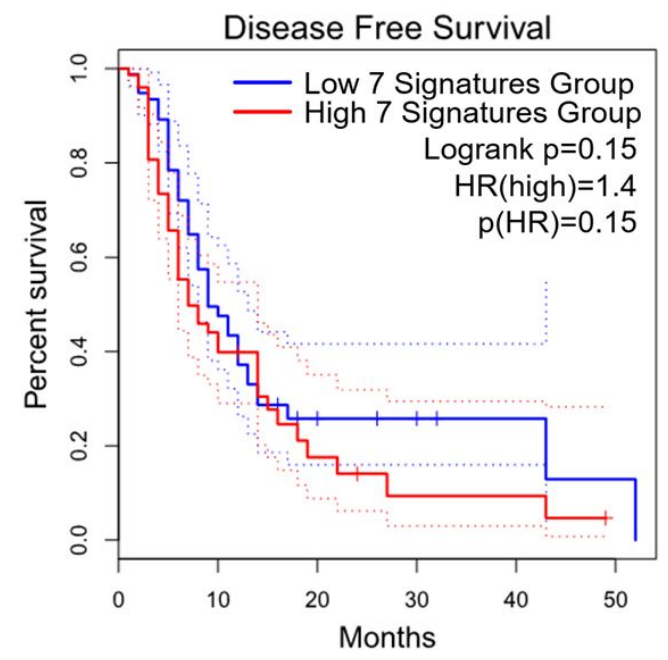

Figure S1: Log-rank test of Disease Free Survival according to the expression of nonlysosomal sulfatase in GBM tumors ( $95 \%$ confidence interval). 


\section{Scheme S1.The synthetic route of MNG \\ Scheme S1.The synthetic route of MNG}<smiles>O=C1OC(=O)c2ccc(Br)c3cccc1c23</smiles>

$\mathrm{C}_{12} \mathrm{H}_{5} \mathrm{BrO}_{3}$

$$
\mathrm{O}_{\mathrm{O}}
$$

1

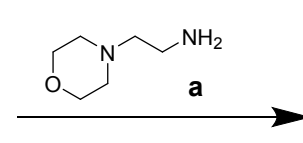

$\mathrm{EtOH}, 90^{\circ} \mathrm{C}, 4 \mathrm{hrs}$

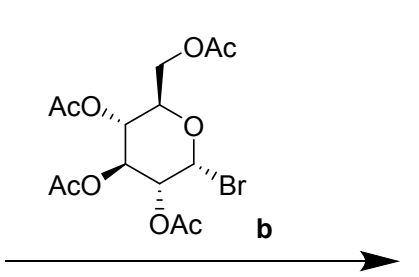

$\mathrm{AgO}, \mathrm{MeCN}, 80^{\circ} \mathrm{C}, 16 \mathrm{hrs}$<smiles>O=C1c2cccc3c(Br)ccc(c23)C(=O)N1CCN1CCOCC1</smiles>

2

$\mathrm{C}_{18} \mathrm{H}_{17} \mathrm{BrN}_{2} \mathrm{O}_{3}$

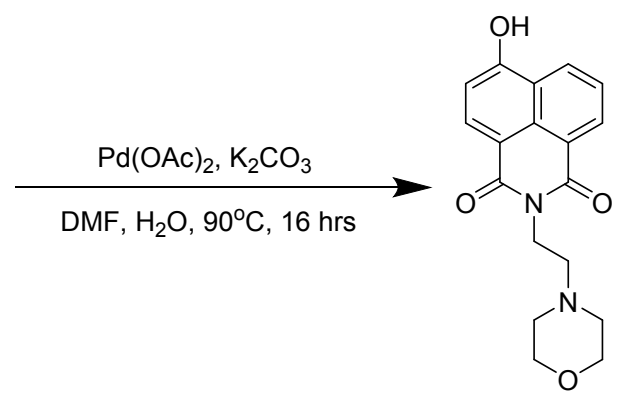

3

$\mathrm{C}_{18} \mathrm{H}_{18} \mathrm{~N}_{2} \mathrm{O}_{4}$

Scheme S1.The synthetic route of MNG. 
Figure S2.Absorption and fluorescence spectra of MNG and MN
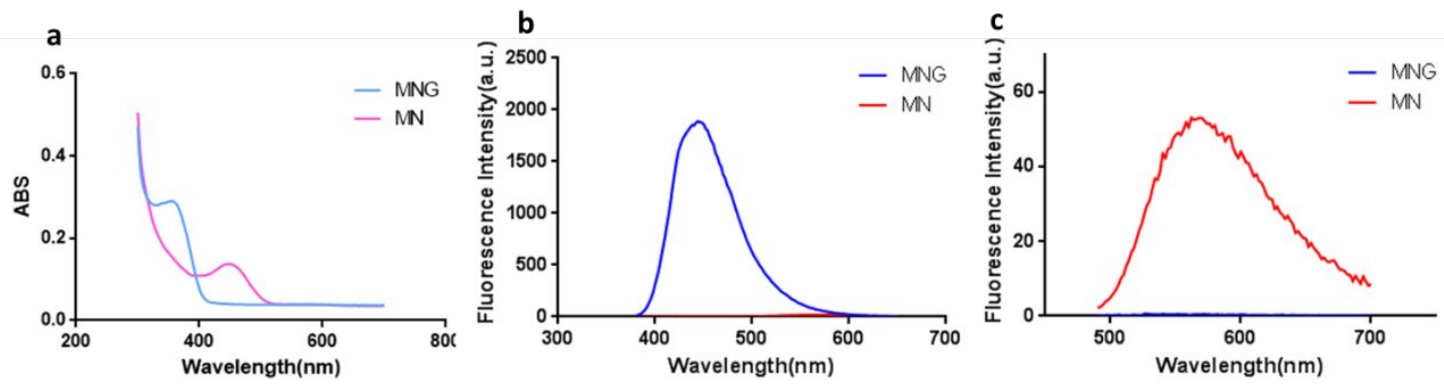

Figure S2. (a)Absorption spectra of MNG and MN $(20 \mu \mathrm{M})$ in the BB buffer $(\mathrm{pH}=5.0)$.

(b)Emission spectra of MNG and $\mathrm{MN}(20 \mu \mathrm{M})$ in BB buffer $(\mathrm{pH}=$ 5.0).ex=360nm.(c)Emission spectra of MNG and $M N(20 \mu M)$ in BB buffer(pH = 5.0).ex=450nm. 
Figure S3. Verify metabolic reaction by MNG

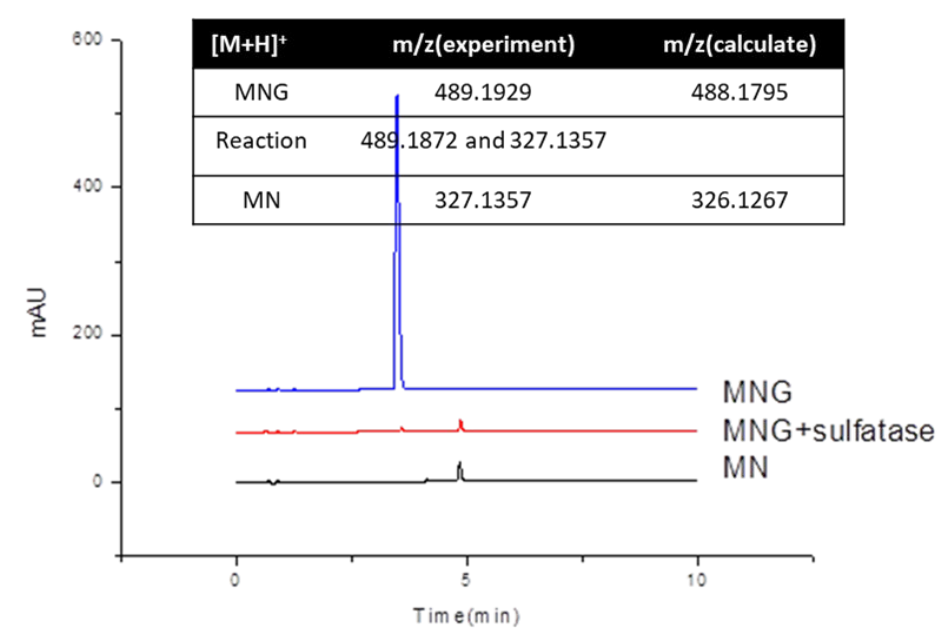

Figure S3 .HPLC-MS validation of sulfatase $(0.2 \mathrm{U} / \mathrm{ml})$-catalyzed probe $(\mathrm{MNG}=20 \mu \mathrm{M})$ metabolism. 
Figure S4. The response of other biomolecules

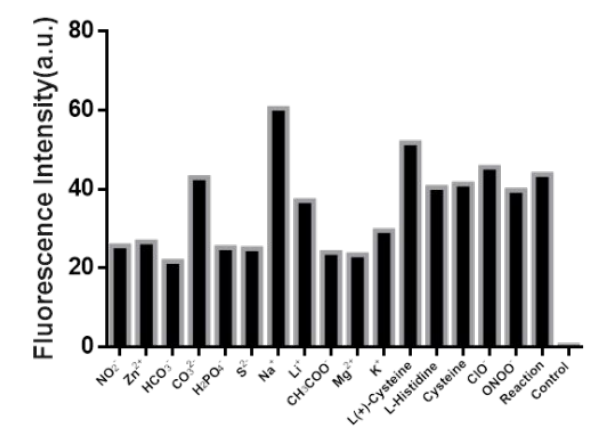

Figure S4. The fluorescence enhancement of MNG $(20 \mu \mathrm{M})$ toward various analytes: $\mathrm{NO}_{2}$, $\mathrm{Zn}^{2+}, \mathrm{HCO}_{3}^{-}, \mathrm{CO}_{3}{ }^{2-}, \mathrm{H}_{2} \mathrm{PO}_{4}^{-}, \mathrm{S}^{2-}, \mathrm{Na}^{+}, \mathrm{Li}^{+}, \mathrm{CH}_{3} \mathrm{COO}^{-}, \mathrm{Mg}^{2+}, \mathrm{K}^{+}, \mathrm{L}(+)$-Cysteine , L-Histidine , Cysteine , $\mathrm{ClO}^{-}, \mathrm{ONOO}^{-}(2 \mathrm{mM})$. The measurement was performed after incubating at $37^{\circ} \mathrm{C}$ for $60 \mathrm{~min}$ in the BB buffer $(\mathrm{pH}=5.0)$. 


\section{Figure S5.The pH effect of MNG and MN}

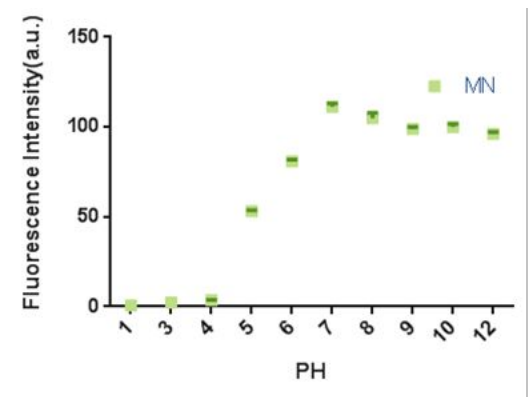

(a)

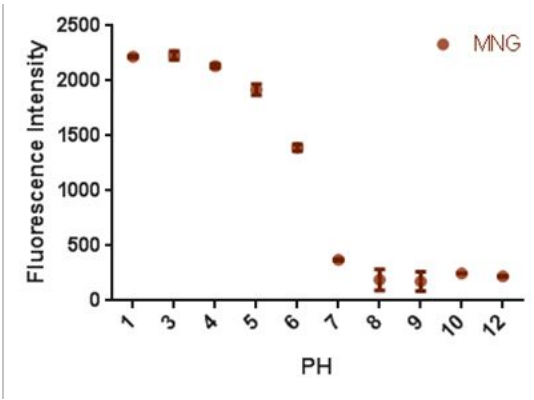

(b)

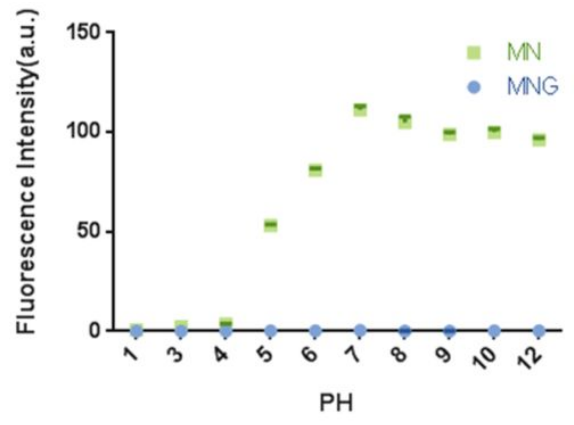

(c)

Figure S5. Fluorescence of MNG and $\mathrm{MN}(20 \mu \mathrm{M})$ in the BB buffer at different $\mathrm{PH}(\mathrm{Ex} / \mathrm{Em}=450 \mathrm{~nm} / 568 \mathrm{~nm})$. The $\mathrm{pH}$ effect results showed that the fluorescence change of probe reaction is obvious at $\mathrm{pH} 5$ which is the optimal pH for lysosomes. 


\section{Figure S6.Photostability detection}

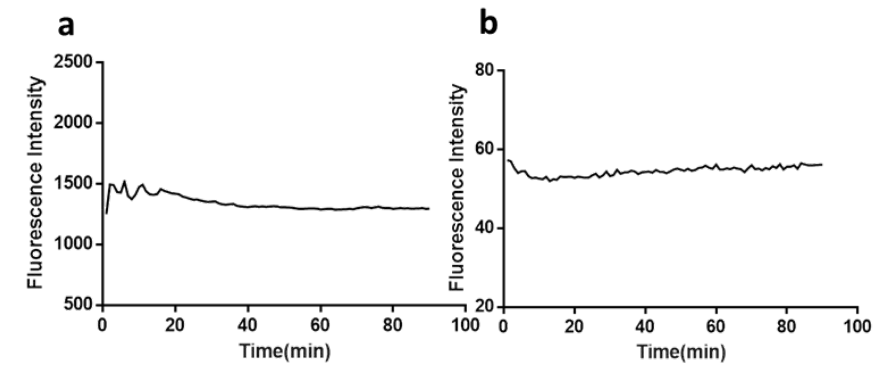

Figure S6. Photostability detection in the present of an iodine-tungsten lamp irradiated for 90 min. (a) MNG (20 $\mu \mathrm{M}, E x=360 \mathrm{~nm})$.(b) $M N(20 \mu \mathrm{M}, \mathrm{Ex}=450 \mathrm{~nm})$. 


\section{Figure S7.Time course of fluorescence of MNG}
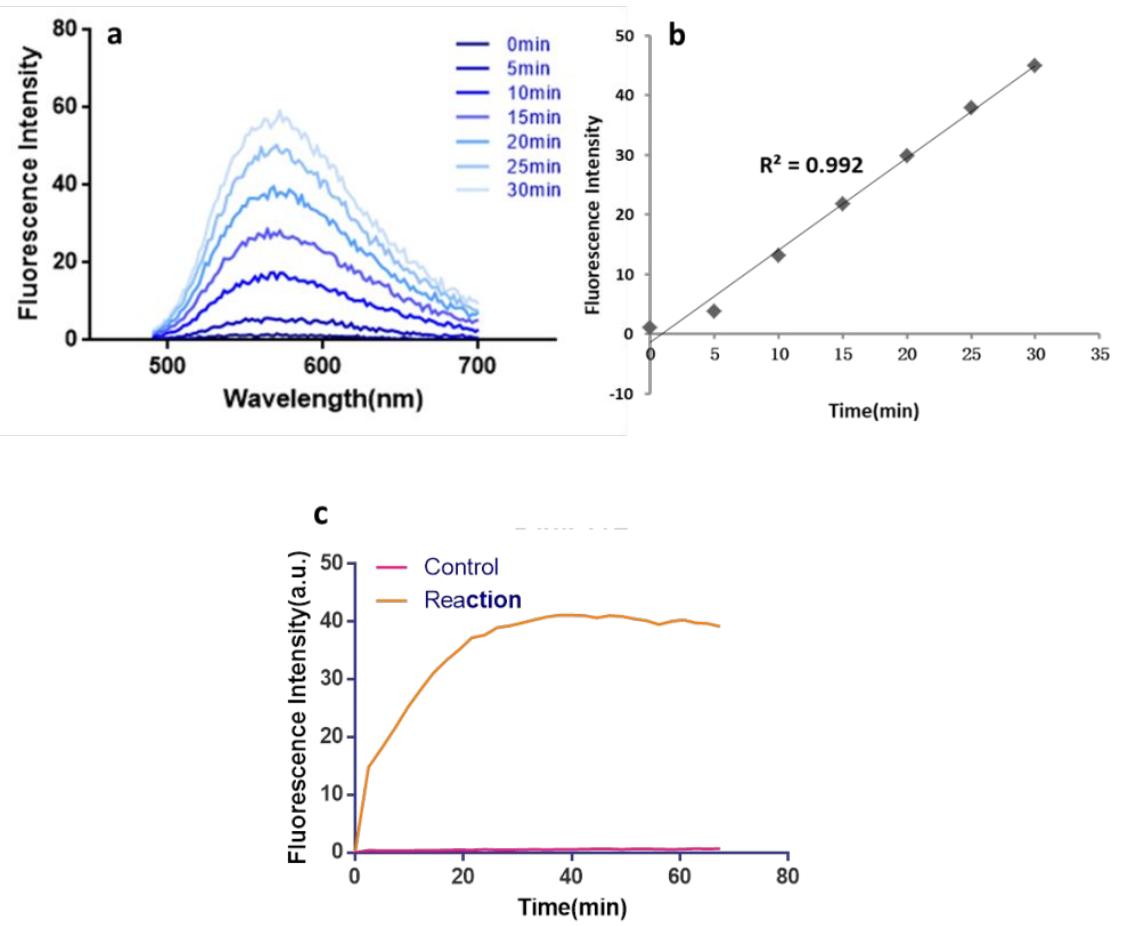

Figure S7. (a)Time course of fluorescence spectra changes of MNG $(20 \mu \mathrm{M})$ in the presence of sulfatase $(0.2 \mathrm{U} / \mathrm{ml})$ at $\mathrm{PH} 5(\mathrm{Ex}=450 \mathrm{~nm})$. (b) Linear relationship between fluorescence intensities of MNG in the presence of sulfatase.(c) The fluorescence intensity of MNG(20 $\mu \mathrm{M})$ as control and its reaction with sulfatase $(0.2 \mathrm{U} / \mathrm{ml})$ in $\mathrm{BB}$ at $37^{\circ} \mathrm{C}(\mathrm{Ex}=450 \mathrm{~nm})$. 
Figure S8.Limit of detection
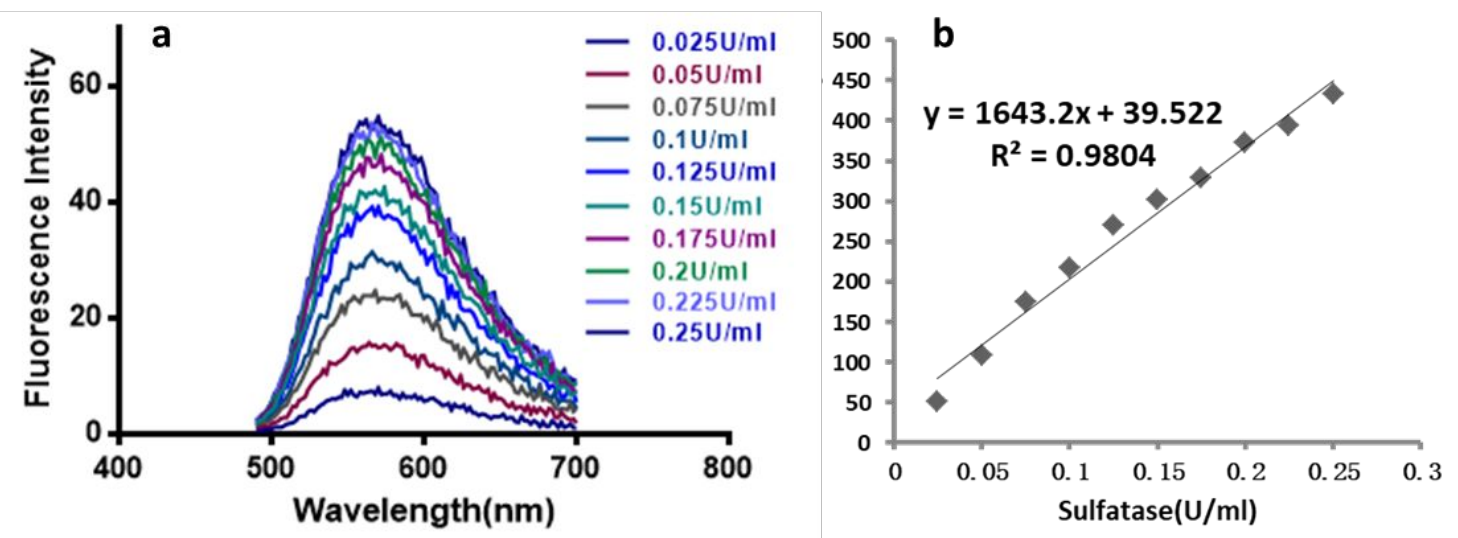

Figure S8 (a) Limit of detection of fluorescence spectra changes of MNG $(20 \mu \mathrm{M})$ in the presence of sulfatase at $\mathrm{PH} 5(\mathrm{Ex}=450 \mathrm{~nm})$. (b) Linear relationship between fluorescence changes of MNG in the presence of sulfatase at PH5. 


\section{Table S1: Kinetic Parameters}

Kinetic parameters.

\begin{tabular}{lllll}
\hline & MNG & $\begin{array}{l}\text { p-nitrocatechol } \\
\text { sulfate(pNCS) }\end{array}$ & $\begin{array}{l}\text { 4-methylumbelliferyl } \\
\text { sulfate(4-MUS) }\end{array}$ \\
\hline & Sulfatase & Human liver cytosol & & \\
\hline $\mathrm{Km}(\mu \mathrm{M})$ & $21.60 \pm 1.85$ & $54.76 \pm 7.13$ & 400 & 12500 \\
\hline $\mathrm{Vmax}(\mathrm{nmol} / \mathrm{min} / \mathrm{mg})$ & $70.93 \pm 1.62$ & $5.17 \pm 0.17$ & 160000 & 40000 \\
\hline
\end{tabular}

${ }^{a}$ Assay was carried out with sulfatase(PH5.5). ${ }^{b}$ Assay was carried out with sulfatase(PH5.7)[1]

Table S1: Kinetic Parameters with various enzymes 


\section{Figure S9 Inhibitor Detection by MNG}

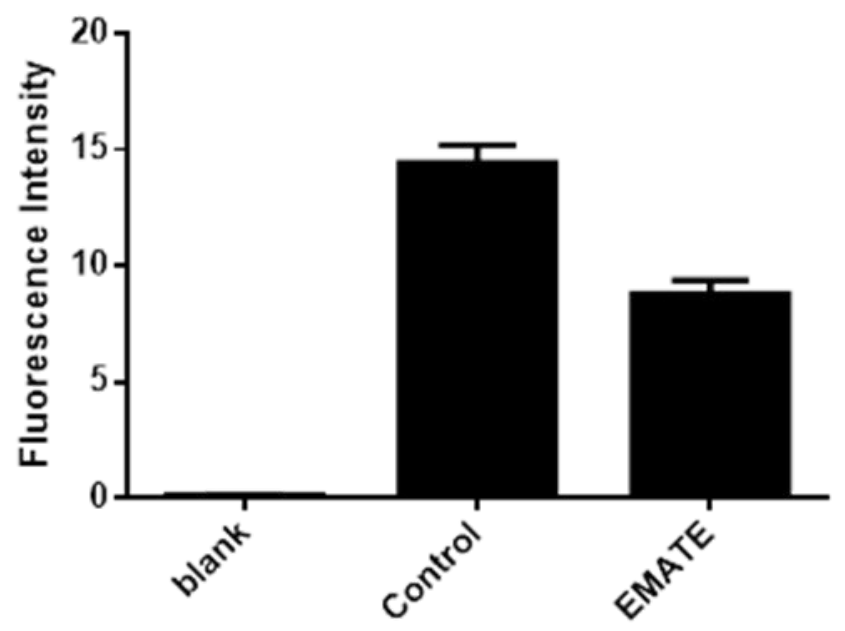

Figure S9. Fluorescence intensities of inhibitor (EMATE. $250 \mu \mathrm{M})$ detected by MNG $(20 \mu \mathrm{M})$ with sulfatase $(0.2 \mathrm{U} / \mathrm{ml})$ and its inhibition is $39 \%$. The intensity of MNG $(20 \mu \mathrm{M})$ with sulfatase in $\mathrm{BB}(\mathrm{PH}=5)$ was set as control and MNG only as blank. 


\section{Table S2: MTT detection of MNG}

\begin{tabular}{|c|c|c|c|c|c|c|}
\hline \multicolumn{7}{|c|}{ T检验 } \\
\hline & \multicolumn{3}{|c|}{ 成对差分 } & \multirow[b]{2}{*}{$t$} & \multirow[b]{2}{*}{$\mathrm{df}$} & \multirow[b]{2}{*}{ Sig. (双侧) } \\
\hline & 均值 & 标准差 & 均值的标准误 & & & \\
\hline MNG \& Control & 1.11478 & 0.51162 & 0.20887 & .550 & 5 & 0.606 \\
\hline
\end{tabular}

$p(s i g)<0.05$, 说明两组显著差异

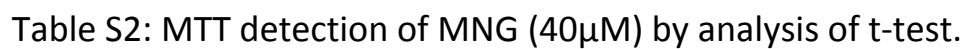




\section{Figure S10.The NMR of compound 2}

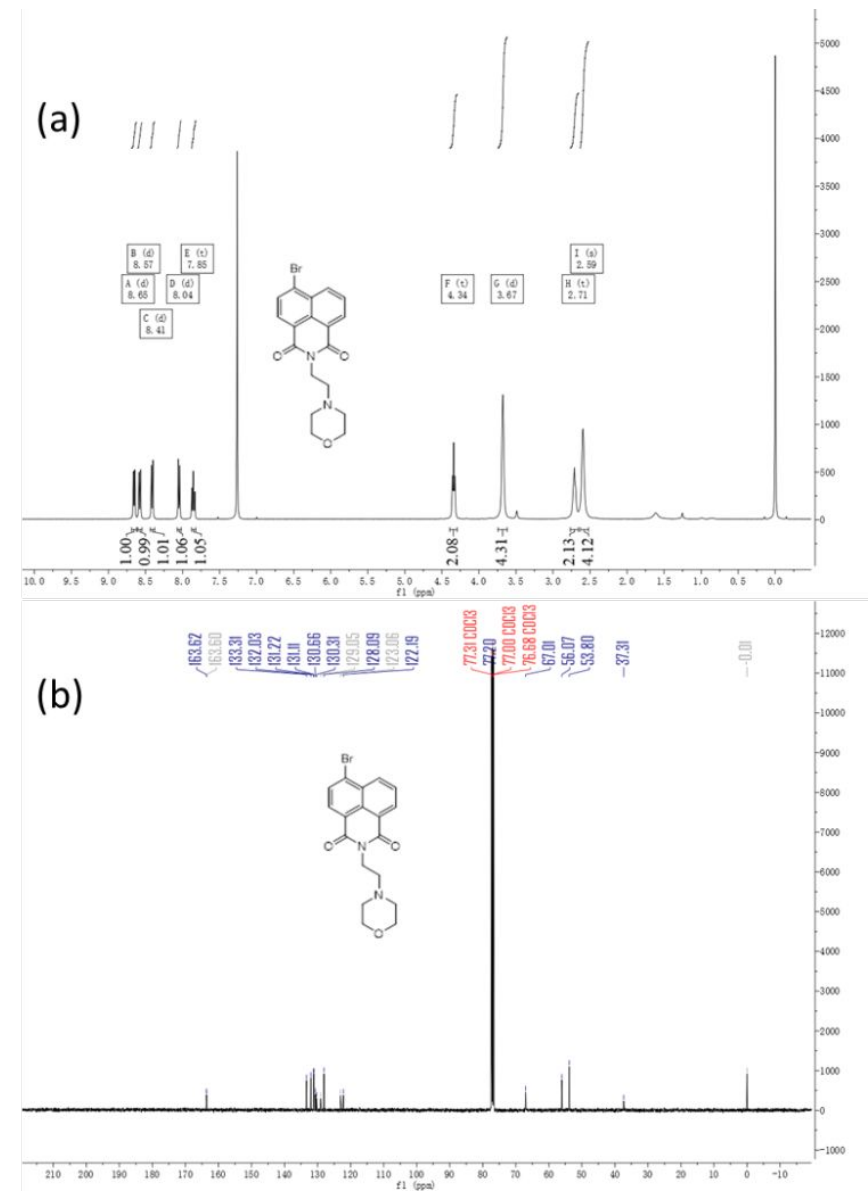

Figure S10. The ${ }^{1} \mathrm{H} N M R(a)$ and ${ }^{13} \mathrm{C} \mathrm{NMR(b)} \mathrm{of}$

6-bromo-2-(2-morpholinoethyl)-1H-benzo[de]isoquinoline-1,3(2H)-dione (2). 


\section{Figure S11.The LC-MS of compound 2}
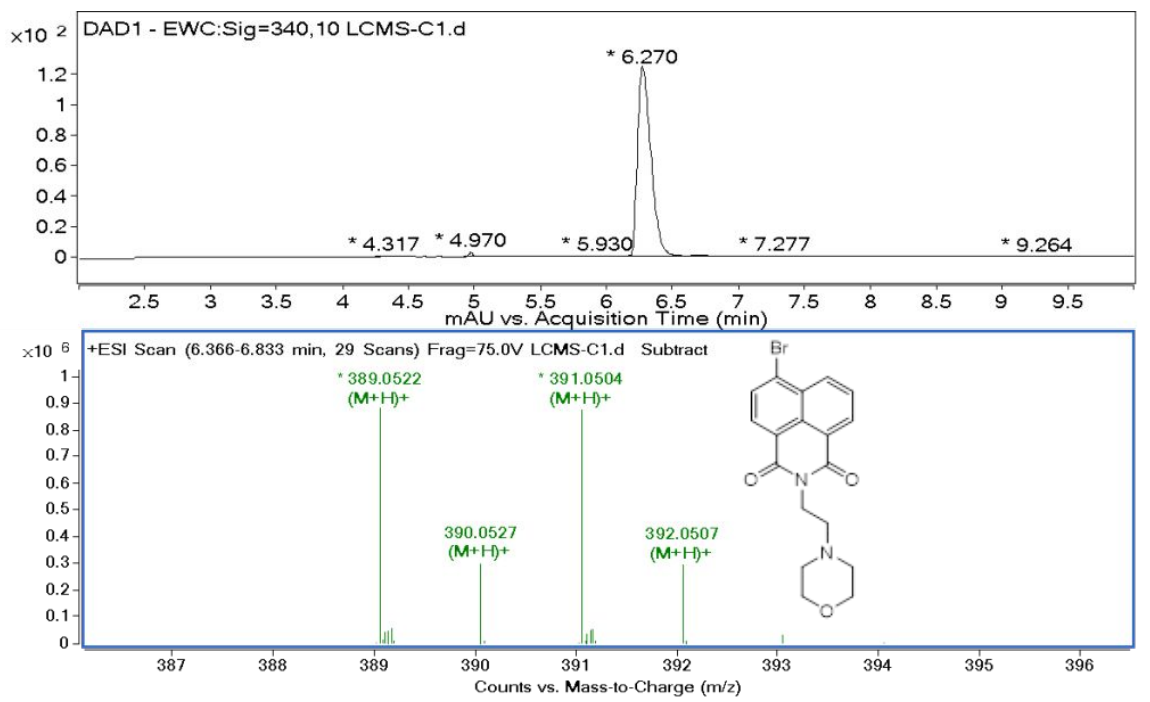

Figure S11. The LC-MS of

6-bromo-2-(2-morpholinoethyl)-1H-benzo[de]isoquinoline-1,3(2H)-dione (2). 


\section{Figure S12.The NMR of compound 3}

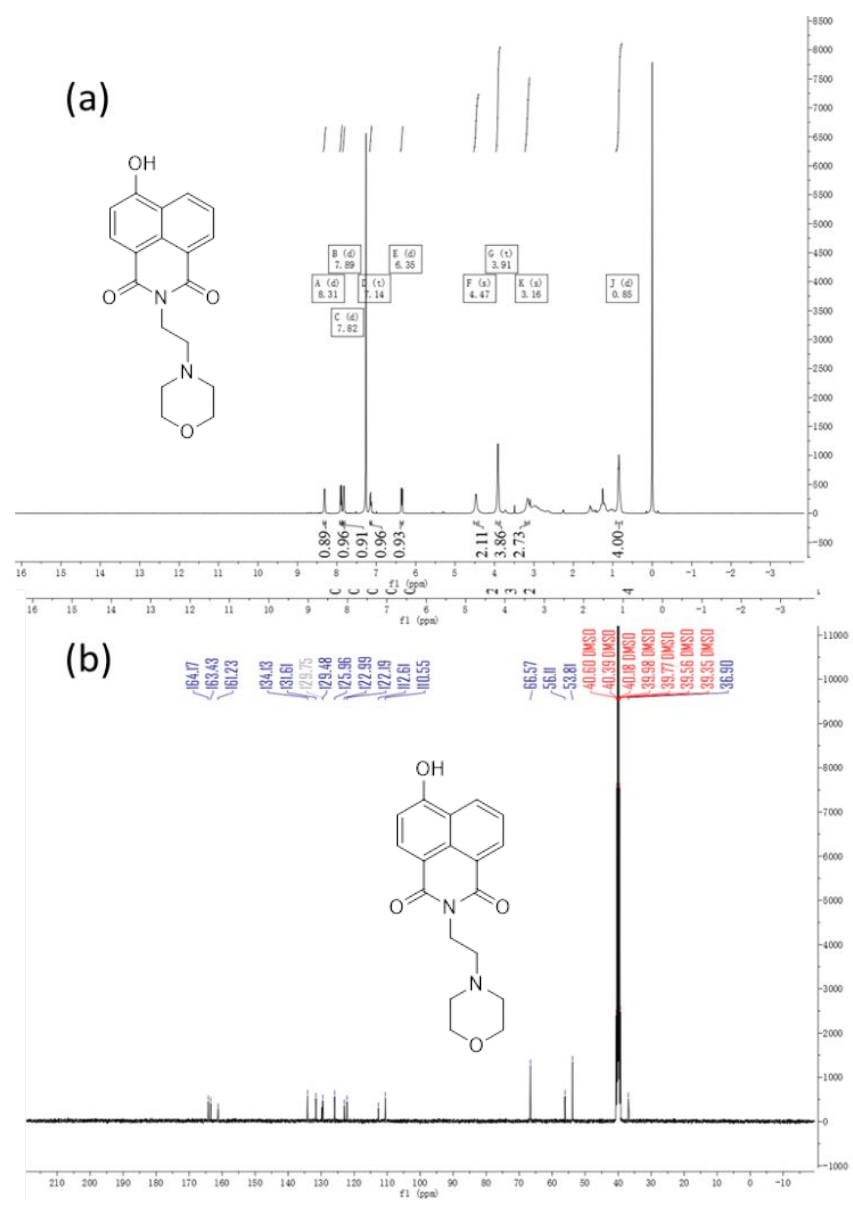

Figure S12. The ${ }^{1} \mathrm{H} N M R(a)$ and ${ }^{13} \mathrm{C} N M R(b)$ of

6-hydroxy-2-(2-morpholinoethyl)-1H-benzo[de]isoquinoline-1,3(2H)-dione (3). 


\section{Figure S13.The LC-MS of compound 3}
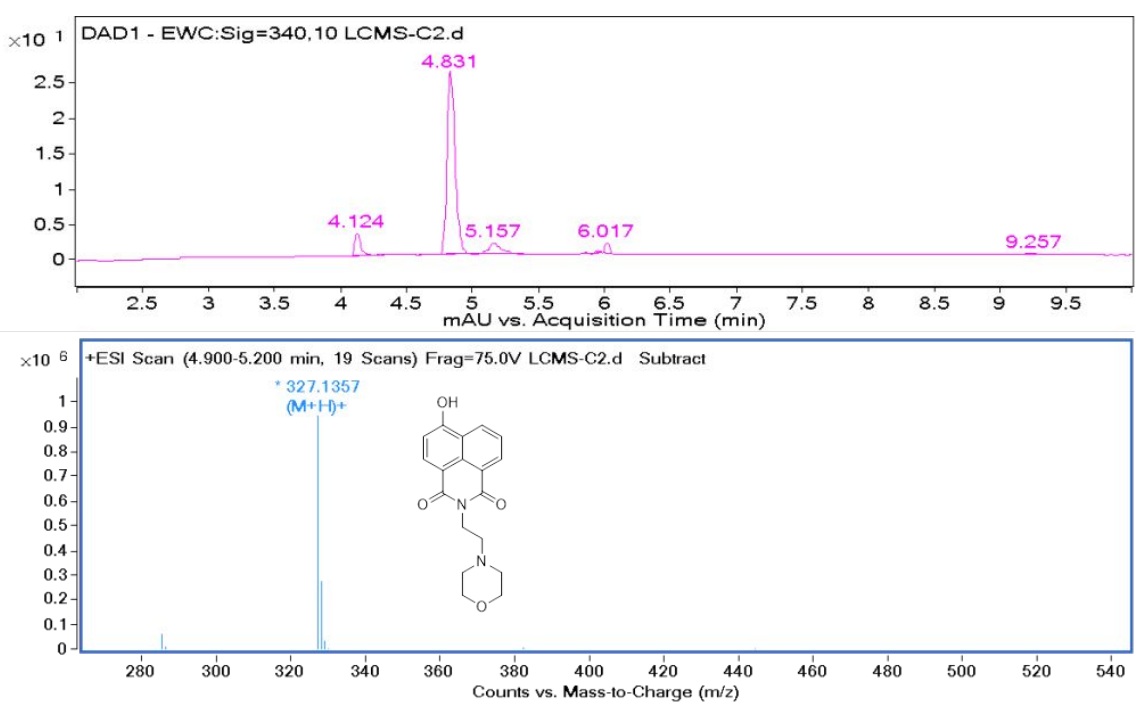

Figure S13.The LC-MS of

6-hydroxy-2-(2-morpholinoethyl)-1H-benzo[de]isoquinoline-1,3(2H)-dione (3). 


\section{Figure S14.The NMR of compound 4}

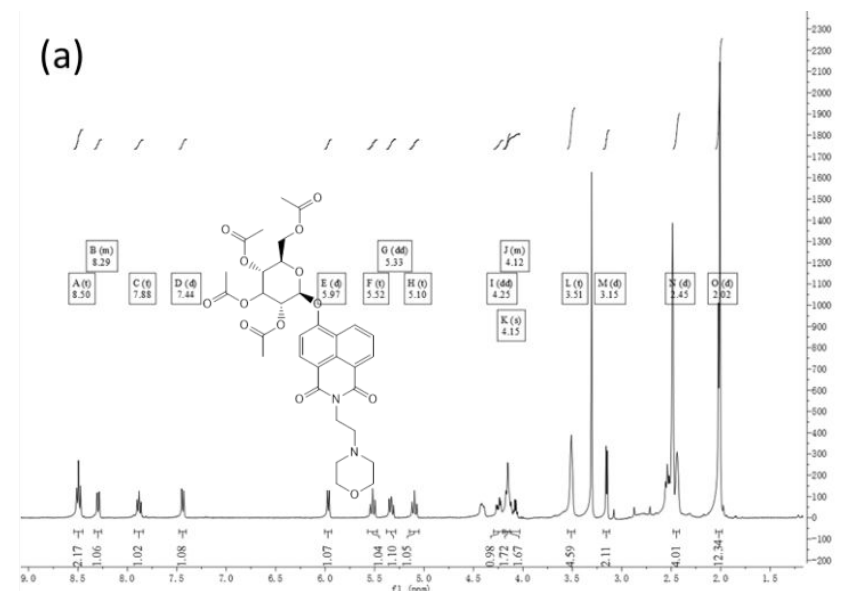

(b)

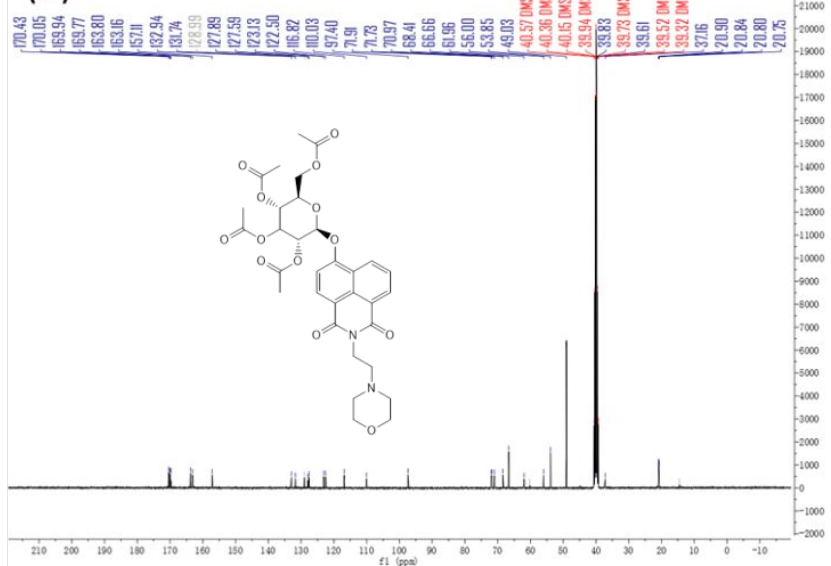

Figure S14. The ${ }^{1} \mathrm{H}$ NMR and ${ }^{13} \mathrm{C}$ NMR of

(2R,3R,4S,5R,6S)-2-(acetoxymethyl)-6-((2-(2-morpholinoethyl)-1,3-dioxo-2,3-dihydro-1H-ben zo[de]isoquinolin-6-yl)oxy)tetrahydro-2H-pyran-3,4,5-triyl triacetate (4). 


\section{Figure S15. The LC-MS of compound 4}

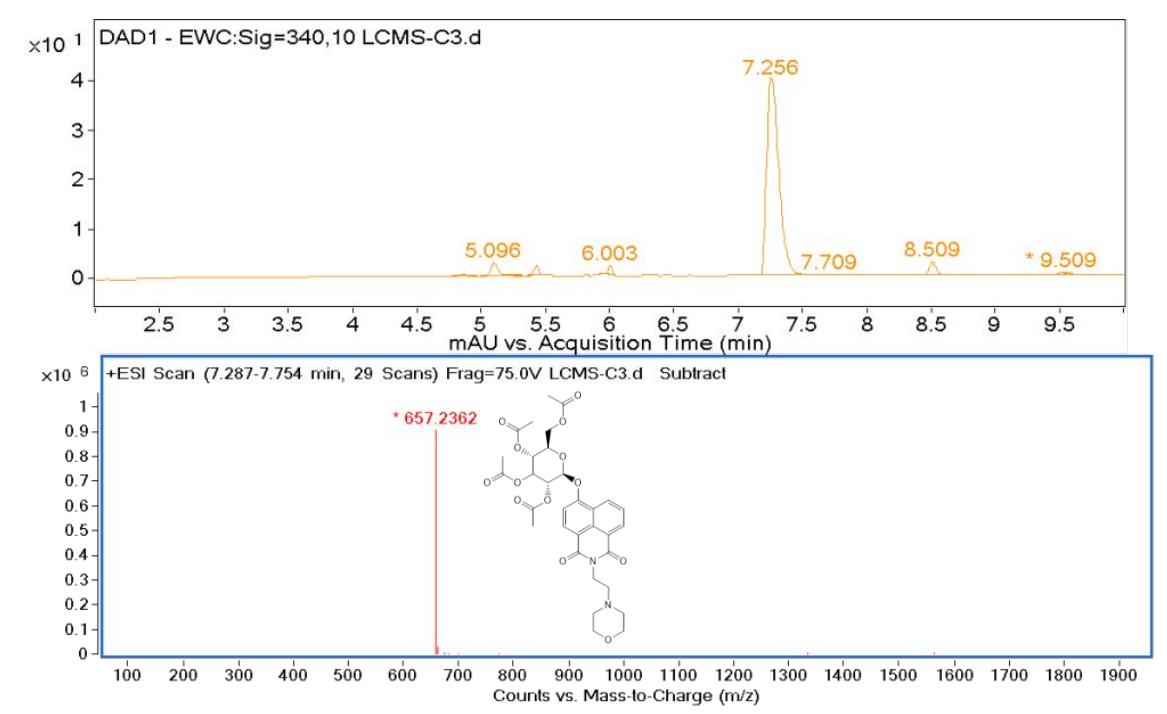

Figure S15.The LC-MS of

(2R,3R,4S,5R,6S)-2-(acetoxymethyl)-6-((2-(2-morpholinoethyl)-1,3-dioxo-2,3-dihydro-1H-ben zo[de]isoquinolin-6-yl)oxy)tetrahydro-2H-pyran-3,4,5-triyl triacetate (4). 
Figure S16. The NMR of MNG

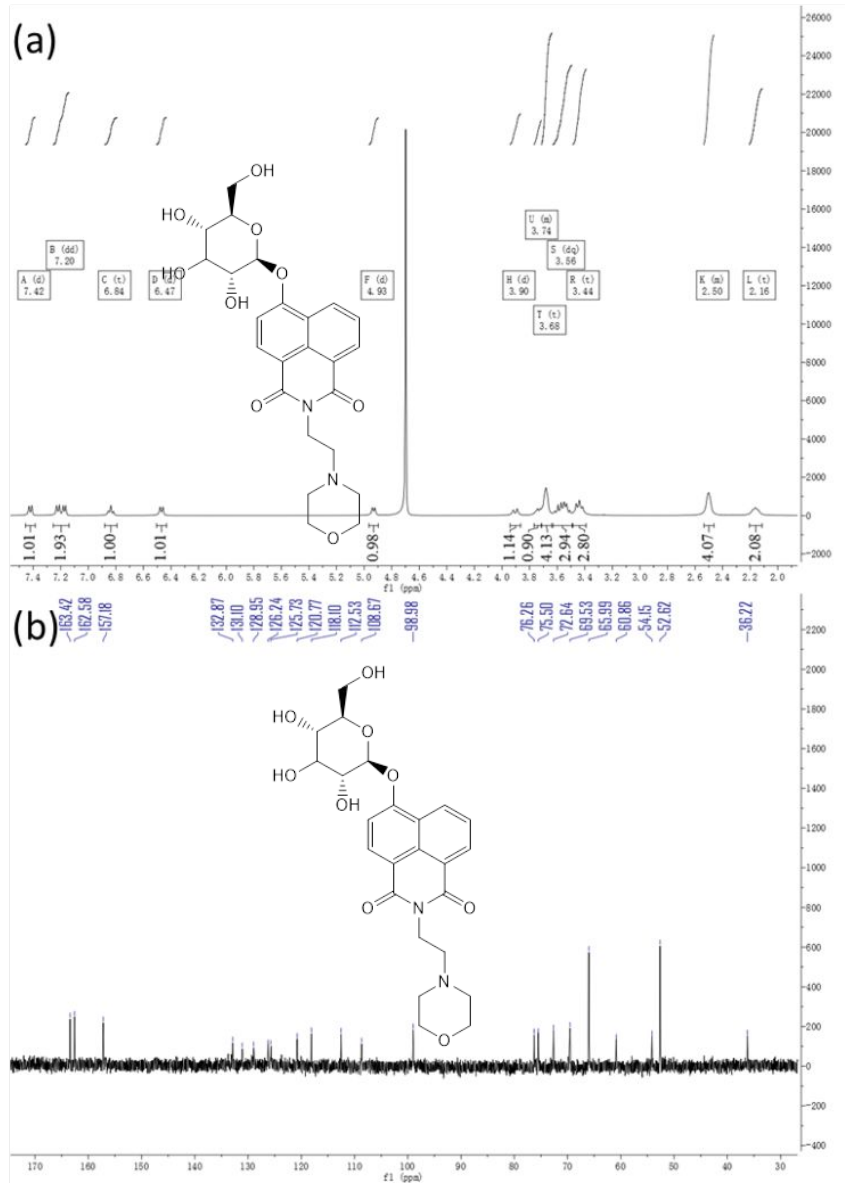

Figure S16. The ${ }^{1} \mathrm{H}$ NMR and ${ }^{13} \mathrm{C}$ NMR of MNG 


\section{Figure S17.The LC-MS of MNG}

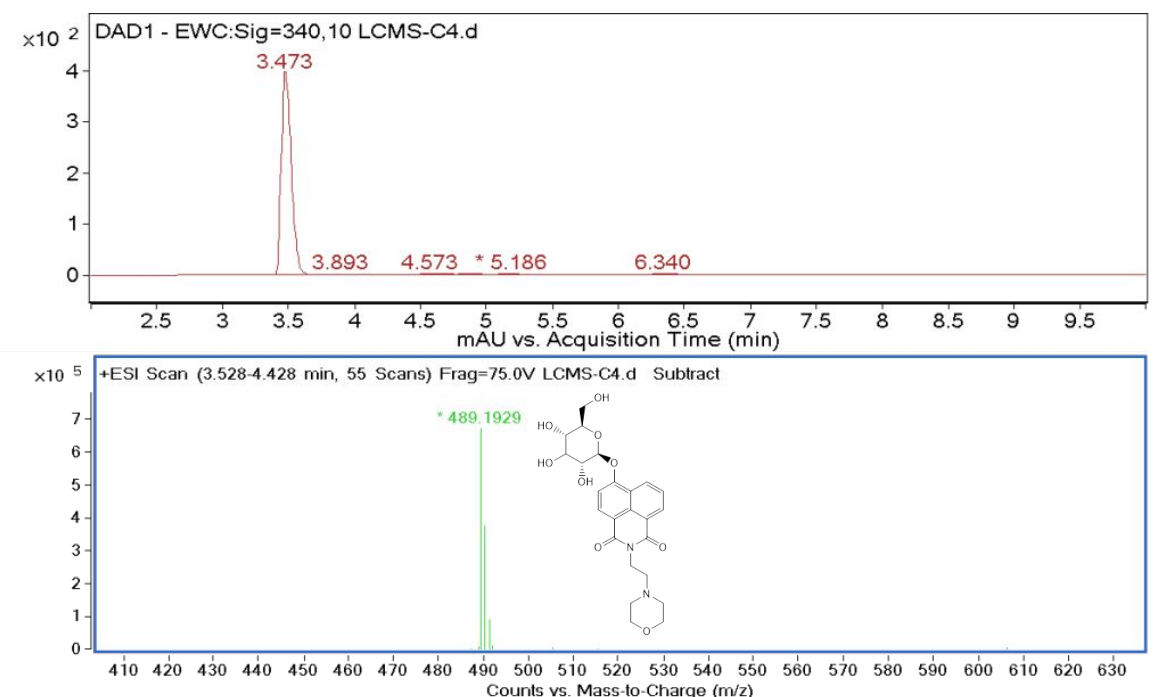

Figure S17.The LC-MS of MNG. 


\section{Table S3. The detailed docking information of complex by molecular docking}

\begin{tabular}{ccccc|}
\hline Mode & $\begin{array}{c}\text { Affinity } \\
\text { (kcal/mol) }\end{array}$ & $\begin{array}{c}\text { Dist from best } \\
\text { mode(rmsd l.b) }\end{array}$ & $\begin{array}{c}\text { Structure } \\
\text { (probe) }\end{array}$ & $\begin{array}{c}\text { Structure } \\
\text { (complex) }\end{array}$ \\
\hline $\mathbf{1}$ & -5.6 & 0.000 & 0.877 \\
$\mathbf{3}$ & -5.6 & 2.237 \\
$\mathbf{4}$ & -5.4 & 2.230 \\
$\mathbf{6}$ & -5.0 & 2.068 \\
$\mathbf{7}$ & -4.9 & 2.302 \\
$\mathbf{8}$ & -4.7 & 1.675 \\
\hline & -4.2 & 4.199 & 2.977
\end{tabular}

Table S3: The detailed docking information of sulfatase-probe complex is analyzed by Autodock Vina, sorted by docking score. 
Figure S18. Root-mean-square Deviation (RMSD) of 20 ns MD Simulations

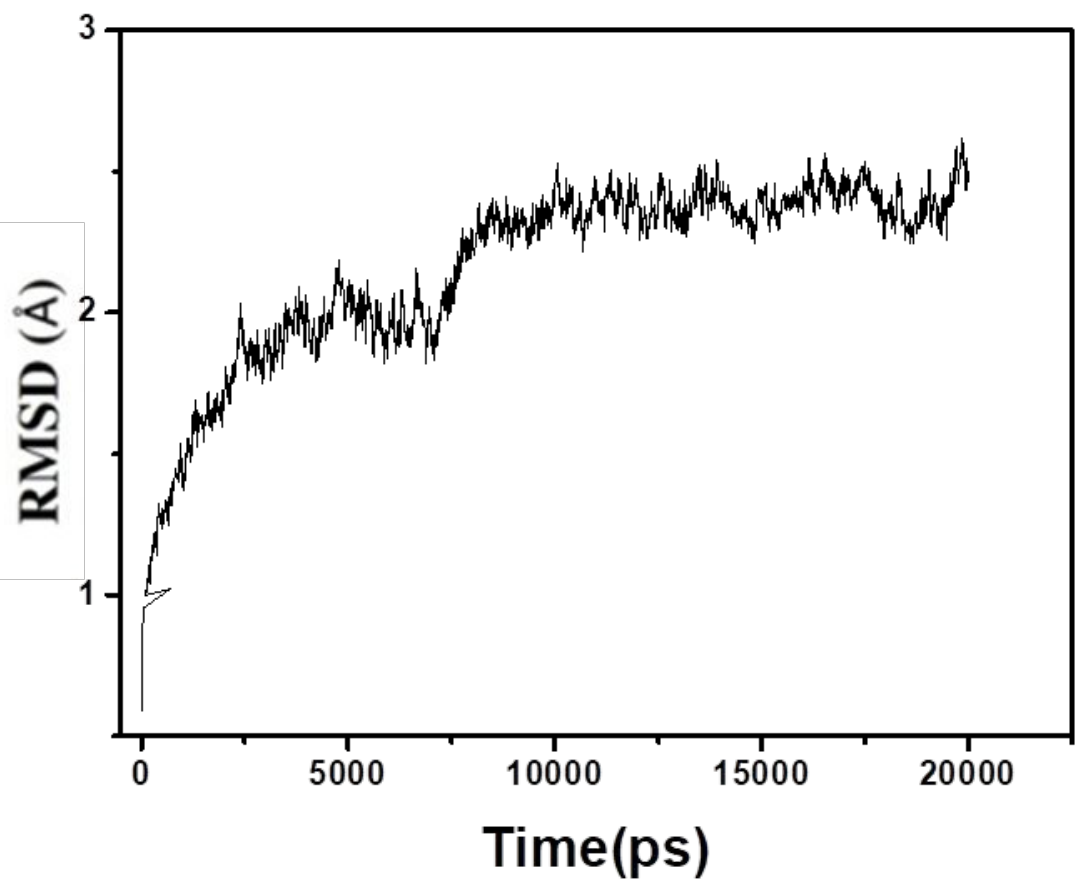

Figure S18. Root-mean-square Deviation (RMSD) of 20 ns MD Simulations. 
Figure S19. The docking model of sulfatase

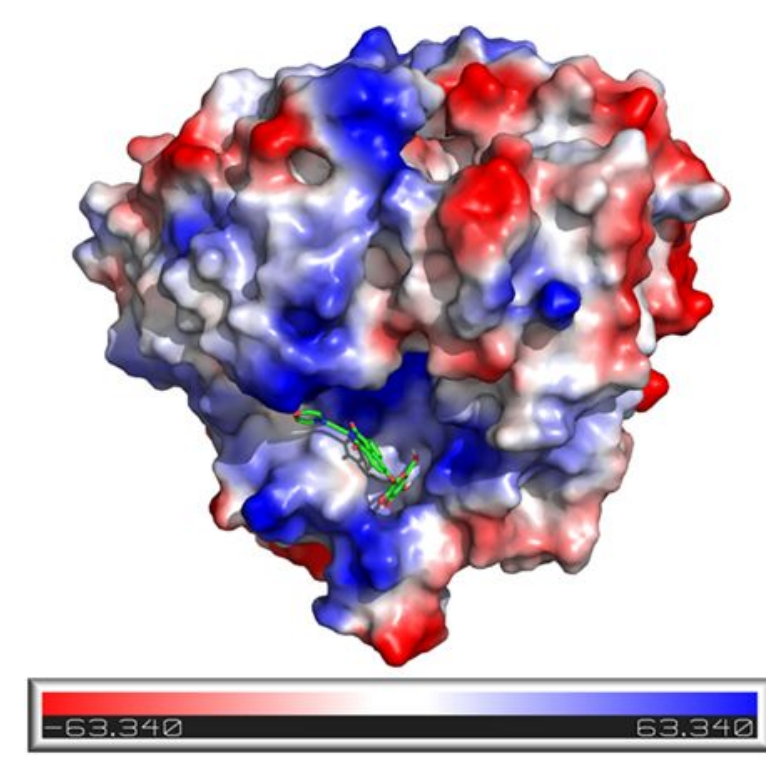

Figure S19: The substrate-binding cleft is colored by vacuum electrostatics potential at the surface from red (negative, $-63.340 \mathrm{kcal} / \mathrm{mol}$ ) to blue (positive, $63.340 \mathrm{kcal} / \mathrm{mol}$ ). 


\section{Molecular formula strings}

\begin{tabular}{lll} 
Compound & SIMLES & IC50 \\
2 & $\mathrm{BrC} 1=\mathrm{CC}=\mathrm{C}(\mathrm{C}(\mathrm{N} 2 \mathrm{CCN} 3 \mathrm{CCOCC} 3)=\mathrm{O}) \mathrm{C} 4=\mathrm{C} 1 \mathrm{C}=\mathrm{CC}=\mathrm{C} 4 \mathrm{C} 2=\mathrm{O}$ & $\mathrm{NA}$ \\
3 & $\mathrm{OC} 1=\mathrm{CC}=\mathrm{C}(\mathrm{C}(\mathrm{N} 2 \mathrm{CCN} 3 \mathrm{CCOCC} 3)=\mathrm{O}) \mathrm{C} 4=\mathrm{C} 1 \mathrm{C}=\mathrm{CC}=\mathrm{C} 4 \mathrm{C} 2=\mathrm{O}$ & $\mathrm{NA}$ \\
& $\mathrm{O}=\mathrm{C}(\mathrm{N}(\mathrm{CCN} 1 \mathrm{CCOCC} 1) \mathrm{C} 2=\mathrm{O}) \mathrm{C} 3=\mathrm{CC}=\mathrm{C}(\mathrm{O}[\mathrm{C} @ \mathrm{H}] 4[\mathrm{C} @ \mathrm{H}](\mathrm{OC}(\mathrm{C})=\mathrm{O})[\mathrm{C}$ & \\
4 & $@ @ @ \mathrm{H}](\mathrm{OC}(\mathrm{C})=\mathrm{O})[\mathrm{C} @ \mathrm{H}](\mathrm{OC}(\mathrm{C})=\mathrm{O})[\mathrm{C} @ @ \mathrm{H}](\mathrm{COC}(\mathrm{C})=\mathrm{O}) \mathrm{O} 4) \mathrm{C} 5=\mathrm{C} 3 \mathrm{C} 2=$ & $\mathrm{NA}$ \\
& $\mathrm{CC}=\mathrm{C} 5$ & \\
MNG & $\mathrm{O}=\mathrm{C}(\mathrm{N}(\mathrm{CCN} 1 \mathrm{CCOCC} 1) \mathrm{C} 2=\mathrm{O}) \mathrm{C} 3=\mathrm{CC}=\mathrm{C}(\mathrm{O}[\mathrm{C} @ \mathrm{H}] 4[\mathrm{C} @ \mathrm{H}](\mathrm{O})[\mathrm{C} @ @ \mathrm{H}]($ & $\mathrm{NA}$ \\
\multirow{2}{*}{ Subactam } & $\mathrm{O})[\mathrm{C} @ \mathrm{H}](\mathrm{O})[\mathrm{C} @ @ \mathrm{H}](\mathrm{CO}) \mathrm{O} 4) \mathrm{C} 5=\mathrm{C} 3 \mathrm{C} 2=\mathrm{CC}=\mathrm{C} 5$ & \\
& $\mathrm{O}=\mathrm{S} 1(\mathrm{C} 2 \mathrm{~N}(\mathrm{C}(\mathrm{C}(\mathrm{OCOC}(\mathrm{C}(\mathrm{C})(\mathrm{C}) \mathrm{C})=\mathrm{O})=\mathrm{O}) \mathrm{C} 1(\mathrm{C}) \mathrm{C}) \mathrm{C}(\mathrm{C} 2)=\mathrm{O})=\mathrm{O}$ & $3.5 \mu \mathrm{M}$
\end{tabular}




\section{Reference}

[1] Hanson S R, Best M D , Wong C H . Sulfatases: Structure, Mechanism, Biological Activity, Inhibition, and Synthetic Utility. Angew Chem Int Ed Engl, 2004, 43,3526-3548. 